\title{
A FORMAÇÃO DO GRUPO “O TEATRO MÁGICO” E O IMPACTO SOCIAL DE SUA OBRA
}

\author{
Mariana Guimarães (IC)
}

\begin{abstract}
Resumo
A música tem importância cultural como difusora de ideias, de emoções e de sentimentos. Para entender a produção musical é preciso buscar compreender a sociedade do tempo em que é elaborada, seus padrões e conflitos. Pensando na música em seu papel crítico e como produtora de sentidos, através da pesquisa busquei analisar se, hoje, há uma forma de expressão artística que cumpra sua função de denunciadora das injustiças sociais. O Teatro Mágico, projeto estudado, teve seu nome e título do primeiro álbum gravado inspirados no livro $O$ Lobo da Estepe, de Hermann Hesse. A análise dessa obra de referência me permite verificar como o grupo se apropria dos conceitos filosóficos e os expressa em sua produção.
\end{abstract}

Palavras Chave: O Teatro Mágico, Música, Educação

\section{Introdução}

O grupo, que também se denomina uma trupe, foi criado pelo ator, músico e compositor Fernando Anitelli, na cidade de Osasco, em 2003. O Teatro Mágico (TM) é um projeto que reúne elementos do circo, do teatro, da poesia, da música, da literatura, da política e do cancioneiro popular tornando possível a junção de diferentes segmentos artísticos numa mesma apresentação. As composições da banda entre o primeiro e segundo discos gravados tratam dos personagens que as pessoas precisam assumir nas diversas situações do cotidiano.

O objetivo foi compreender como o grupo se formou e veio a produzir um projeto singular. Para isso foi preciso investigar as relações entre a obra de arte e a sociedade em que foi produzida, bem como os anseios e expectativas do artista que a criou.

\section{Resultados e Discussão}

A partir da pesquisa e das análises feitas pudemos relacionar as teorias de Elias e Bourdieu, de que a produção da obra de arte é diretamente dependente da relação do sujeito autor com a sociedade em que vive e os vínculos que constrói socialmente, com a história de Fernando e seu Teatro Mágico. O sucesso da criação é resultado das vivências nos ambientes frequentados pelo sujeito, do meio em que está inserido, de tudo que carrega consigo no trajeto de sua vida. As relações que Fernando travou durante sua juventude, com pessoas que tinham anseios parecidos e estavam envolvidas nos mesmos tipos de projeto, foram fundamentais para o sucesso de seu projeto particular. $O$ grupo O Teatro Mágico se formou a partir de tudo o que havia vivido até então: das expressões artísticas que aconteciam simultaneamente reunidas num mesmo ambiente - os de sarau; das pessoas que conheceu; das aulas de teatro e oficinas circenses; da leitura de um livro - O Lobo da Estepe - que fez com que ele percebesse a pluralidade de seres que somos em um único corpo, e como assumimos uma personalidade específica de acordo com as situações cotidianas que devemos enfrentar; e da maneira como queria representar isso no palco para levar às pessoas mensagens que não fossem efêmeras.

\section{Conclusões}

Bourdieu (2008) fala da gênese, a partir de sua reconstrução: "Ao fazer com que ressurjam os conflitos e os confrontos dos primeiros momentos (...) ela reatualiza a possibilidade de que houvesse sido (e de que seja) de outro modo e, por meio dessa utopia prática, recoloca em questão o possível que se concretizou entre todos os outros" (p. 98). Por vezes, nos questionamos sobre se tomamos as decisões certas na vida, os famosos "se..." surgem e nos fazem viver na fantasia de que as coisas poderiam ter sido diferentes. Mas o tempo não volta atrás, portanto tudo o que produzimos e somos é decorrente de um conjunto de fatos concretos, das escolhas que fazemos e caminhos que seguimos.

\section{Agradecimentos}

\section{$\mathrm{PIBIC} / \mathrm{CNPq}$}

BOURDIEU, Pierre. "Espíritos de estado: Gênese e estrutura do campo burocrático". In Razões Práticas: sobre a teoria da ação. Tradução de Mariza Corrêa. $9^{a}$ ed. CAMPINAS, SP: PAPIRUS EDITORA, 2008, pp. 91-123.

${ }^{2}$ ELIAS, Norbert. Mozart, Sociologia de um Gênio. Tradução de

Sergio Goes de Paula. RIO DE JANEIRO, RJ: ZAHAR, 1995, 150p.. 